\title{
PENINGKATAN EFEKTIVITAS CUKA DENGAN PENAMBAHAN LARUTAN BUAH LERAK TERHADAP GULMA Cyperus rotundus, Eleusine indica, DAN Synedrella nodiflora
}

\author{
Muhammad Reza Gemilang, Hidayat Pujisiswanto \& Nanik Sriyani \\ Jurusan Agroteknologi, Fakultas Pertanian Universitas Lampung \\ J1. Prof. Soemantri Brodjonegoro, No.1, Bandar Lampung 35145 \\ E-mail: mrezagemilang@gmail.com
}

\begin{abstract}
ABSTRAK
Gulma merupakan tumbuhan pengganggu yang dapat menghambat pertumbuhan dan hasil produksi tanaman. Cuka dapat dimanfaatkan sebagai herbisida karena memiliki mekanisme kerja mirip paraquat dan buah lerak mengandung saponin yang diduga dapat meningkatkan efektivitas cuka. Penelitian ini bertujuan untuk 1). Menguji larutan buah lerak (Sapindus rarak) sebagai ajuvan herbisida untuk meningkatkan efektivitas cuka dalam mengendalikan gulma; 2). Mendapatkan kombinasi campuran cuka dan larutan buah lerak pada konsentrasi cuka yang lebih rendah dari 20\% tanpa mengurangi efektivitas dalam mengendalikan gulma. Penelitian ini dilakukan di Laboratorium Lapang Terpadu Fakultas Pertanian Universitas Lampung pada bulan April hingga bulan Mei 2016. Penelitian ini merupakan percobaan faktorial yang disusun dalam Rancangan Acak Kelompok dengan 4 ulangan. Faktor pertama adalah cuka dengan konsentrasi 0, 5, 10, 15, dan 20\%. Faktor kedua adalah konsentrasi larutan buah lerak yaitu 0, 2,5, dan 5\%. Perlakuan sebanyak 15 perlakuan diulang sebanyak 4 kali dengan 3 jenis gulma sasaran sehingga diperoleh 180 satuan percobaan. Uji Beda Nyata Terkecil (BNT) pada taraf 5\% digunakan untuk menguji nilai tengah antar perlakuan. Hasil penelitian menunjukkan bahwa 1). Penambahan larutan buah lerak 2,5\% dan 5\% kedalam cuka sebagai ajuvan mampu meningkatkan keracunan terhadap gulma C. rotundus dan E. indica pada konsentrasi cuka $15 \%$; 2). Kombinasi cuka dan larutan buah lerak dibawah $20 \%$ yang memiliki efektivitas yang sama dengan cuka $20 \%$ adalah $15 \%+2,5 \%$ pada gulma $C$. rotundus dan $S$. nodiflora yang ditandai dengan menurunnya tingkat kehijauan daun dan bobot kering gulma.
\end{abstract}

Kata kunci : Ajuvan, Buah Lerak, Cuka, Efektivitas, Gulma

\section{PENDAHULUAN}

Gulma merupakan tumbuhan yang mengganggu atau merugikan kepentingan manusia. Kehadiran gulma pada lahan budidaya mengakibatkan terjadinya kompetisi unsur hara, air, cahaya matahari, dan ruang tumbuh sehingga menyebabkan turunnya produksi tanaman (Pujisiswanto, 2012). Pengendalian kimiawi dengan menggunakan herbisida menjadi pilihan utama dibandingkan dengan cara lain karena dinilai lebih efektif dan lebih efisien dalam hal waktu dan biaya. Meskipun menjadi pilihan utama, dampak pengendalian menggunakan herbisida yang sama secara terus menerus adalah munculnya resiko pencemaran lingkungan akibat residu bahan aktif herbisida dan resistensi gulma. Oleh karena itu diperlukan alternatif herbisida dengan bahan aktif yang lebih ramah lingkungan.

Menurut Chinery (2002), cuka makanan (asam asetat) dapat digunakan sebagai bioherbisida. Mekanisme kerja dari asam asetat adalah mirip dengan paraquat dimana asam asetat menyebabkan pembubaran cepat keutuhan membran sel mengakibatkan pengeringan jaringan daun, dan akhirnya kematian tumbuhan. Aplikasi asam asetat 10\% - $20 \%$ mampu mengendalikan pertumbuhan Asystasia gangetica, sedangkan kacangan (LCC) dan Mikania micranta mampu dikendalikan dengan konsentrasi 20\% sampai dengan 4 MSA (Pujisiswanto, 2012). Namun dalam aplikasinya, konsentrasi cuka yang digunakan sebagai herbisida masih terlalu tinggi sehingga perlu penambahan ajuvan untuk menurunkan konsentrasi cuka. Menurut Syahroni et al. (2013), saponin terdapat pada semua bagian tanaman Sapindus dengan kandungan tertinggi terdapat pada bagian buah bersifat menyerupai sabun. Penambahan zat saponin yang terkandung dalam buah lerak diperkirakan dapat menambah efikasi cuka dan menurunkan konsentrasi cuka yang diperlukan tanpa menurunkan efektivitas dalam mengendalikan gulma.

Penelitian ini bertujuan untuk 1). Menguji larutan buah lerak (Sapindus rarak) sebagai ajuvan herbisida untuk meningkatkan efektivitas cuka dalam mengendalikan gulma; 2). Mendapatkan kombinasi 
campuran cuka dan larutan buah lerak pada konsentrasi cuka yang lebih rendah dari $20 \%$ tanpa mengurangi efektivitas dalam mengendalikan gulma.

\section{BAHAN DAN METODE}

Penelitian ini dilaksanakan di rumah kaca Laboratorium Lapangan Terpadu dan Laboratorium Gulma, Fakultas Pertanian, Universitas Lampung, Kecamatan Rajabasa, Kota Bandar Lampung, Provinsi Lampung. Penelitian ini dilaksanakan dari bulan April 2016 sampai bulan Mei 2016. Penelitian ini merupakan percobaan faktorial yang disusun dalam Rancangan Acak Kelompok dengan 4 ulangan. Faktor pertama adalah cuka dengan konsentrasi $0,5,10,15$, dan $20 \%$. Faktor kedua adalah konsentrasi larutan buah lerak yaitu $0,2,5$ dan 5\%. Perlakuan sebanyak 15 perlakuan diulang sebanyak 4 kali dengan 3 jenis gulma sasaran sehingga diperoleh 180 satuan percobaan. Beda Nyata Terkecil (BNT) pada taraf 5\% digunakan untuk menguji perbedaan nilai tengah.

Gulma sasaran terdiri atas 3 spesies gulma dari 3 golongan : teki (Cyperus rotundus), rumputan (Eleusine indica), dan daun lebar (Synedrella nodiflora). Penanaman gulma dilakukan dengan menanam gulma yang masih muda. Kalibrasi dilakukan dengan menggunakan metode luas dan didapat volume semprot yang dibutuhkan sebesar 500 1/ha. Aplikasi campuran cuka dan larutan buah lerak dilakukan hanya satu kali selama pengujian pada umur gulma 2 minggu setelah tanam (MST), dimulai dari konsentrasi paling rendah sehingga menghindari bias data

Variabel yang diamati yaitu tingkat keracunan gulma, tingkat kehijauan daun, anatomi stomata daun yang diamati pada $3 \mathrm{HSA}$, dan bobot kering gulma yang diamati pada 6 HSA.

\section{HASIL DAN PEMBAHASAN}

\section{Keracunan Gulma}

Perlakuan cuka dan larutan buah lerak menyebabkan keracunan pada daun gulma ditandai dengan daun yang mengalami klorosis atau menguning bahkan kematian gulma. Menurut Nurtjahyani dan Murtini (2015), klorosis adalah bercak-bercak kuning pada daun yang akan melebar dan pinggir bercak memiliki warna lenih tua dibandingkan tengahnya. Klorosis disebabkan karena daun mengalami kerusakan atau luruhnya klorofil sehingga daun tidak berwarna hijau, melainkan berwarna kuning atau hampir putih. Menurut Pujisiswanto (2015), aplikasi asam asetat menurunkan kadar klorofil sehingga menyebabkan penghambatan laju fotosintesis gulma.

Hasil analisis ragam menunjukkan bahwa peningkatan keracunan gulma C. rotundus, E. indica, dan $S$. nodiflora dipengaruh interaksi konsentrasi cuka dan konsentrasi larutan buah lerak. Perlakuan cuka dan larutan buah lerak menyebabkan keracunan pada daun gulma C. rotundus dimulai pada konsentrasi 15$20 \%$ yang ditandai adanya daun yang mengalami klorosis (Gambar 1). Hasil uji lanjut dengan BNT 5\% (Tabel 1) pada $C$. rotundus menunjukkan bahwa penggunaan cuka 20\% tanpa ditambahkan larutan buah lerak memiliki tingkat keracunan lebih tinggi dibandingkan dengan kontrol. Penambahan larutan buah lerak 2,5\% dan 5\% mampu meningkatkan keracunan gulma pada konsentrasi cuka 15\%. Berdasarkan kriteria Komisi Pestisida (2011), seluruh keracunan yang terjadi pada $C$. rotundus termasuk keracunan ringan $(<20 \%)$ kecuali pada perlakuan cuka $20 \%+5 \%$ larutan buah lerak yang mengalami keracunan sedang $(>20-50 \%)$.

Aplikasi campuran cuka dan larutan buah lerak menyebabkan keracunan pada gulma $E$. indica yang ditandai dengan gejala pemutihan (bleaching) yang dimulai pada aplikasi cuka $10 \%$ tunggal dan campuran larutan buah lerak (Gambar 2). Aplikasi terhadap $E$. indica (Tabel 2) menunjukkan bahwa penggunaan cuka $15 \%$ tanpa campuran, dan pada lerak 2,5 dan $5 \%$, konsentrasi cuka $10 \%$ memiliki tingkat keracunan lebih tinggi dibandingkan dengan kontrol. Pada konsentrasi cuka $10-20 \%$, pemberian campuran buah lerak 2,5 dan $5 \%$ mampu meningkatkan keracunan gulma dibandingkan dengan cuka tunggal. Tingkat keracunan gulma pada aplikasi cuka 10\%+2,5\%,10\%+5\% larutan buah lerak, dan $15 \%$ tanpa campuran menyebabkan keracunan ringan, aplikasi $15 \%+2,5 \%, 15 \%+5 \%$ larutan buah lerak, dan $20 \%$ tanpa campuran menyebabkan keracunan sedang, aplikasi 20\% +2,5\% larutan buah lerak menyebabkan keracunan berat, dan aplikasi $20 \%+5 \%$ larutan buah lerak menyebabkan keracunan sangat berat. Aplikasi cuka 10\% - 20\% tunggal dan campuran larutan buah lerak menyebabkan terjadinya perubahan warna daun yang semula hijau menjadi kuning hingga keputihan (Gambar 3). Aplikasi terhadap S. nodiflora (Tabel 3) menunjukkan bahwa penggunaan cuka $10 \%$ tanpa campuran, dan pada lerak 2,5 dan $5 \%$, konsentrasi cuka $10 \%$ memiliki tingkat keracunan lebih tinggi dibandingkan dengan kontrol. Hasil pengamatan tingkat keracunan menunjukkan bahwa gulma $S$. nodiflora mengalami keracunan sangat berat (>75\%) dimulai dari aplikasi cuka $10-20 \%$. 
Tabel 1. Pengaruh Perlakuan Cuka + Larutan Buah Lerak Terhadap Tingkat Keracunan Gulma Cyperus rotundus pada 3 HSA

\begin{tabular}{|c|c|c|c|c|c|c|}
\hline \multirow{2}{*}{$\begin{array}{c}\text { Cuka } \\
(\%)\end{array}$} & \multicolumn{6}{|c|}{ Lerak $(\%)$} \\
\hline & 0 & & 2,5 & & 5 & \\
\hline \multirow{2}{*}{0} & 0 & $\mathrm{a}$ & 0 & $\mathrm{a}$ & 0 & $\mathrm{a}$ \\
\hline & A & & A & & A & \\
\hline \multirow{2}{*}{5} & 0 & $\mathrm{a}$ & 0 & $\mathrm{a}$ & 0 & a \\
\hline & A & & A & & A & \\
\hline \multirow{2}{*}{10} & 0 & $\mathrm{a}$ & 0 & $\mathrm{a}$ & 0 & $\mathrm{a}$ \\
\hline & A & & A & & $\mathrm{A}$ & \\
\hline \multirow{2}{*}{15} & 0 & $\mathrm{a}$ & 13,75 & b & 15,75 & $\mathrm{~b}$ \\
\hline & $\mathrm{A}$ & & B & & B & \\
\hline \multirow{2}{*}{20} & 14,75 & $\mathrm{~b}$ & 16,25 & $\mathrm{c}$ & 21,25 & $\mathrm{c}$ \\
\hline & $\mathrm{A}$ & & $\mathrm{A}$ & & B & \\
\hline
\end{tabular}

Keterangan : Angka-angka yang diikuti huruf sama, huruf kecil untuk kolom dan huruf besar untuk baris, tidak berbeda menurut uji BNT 5\%=2,19

Tabel 2. Pengaruh Perlakuan Cuka + Larutan Buah Lerak Terhadap Tingkat Keracunan Gulma Eleusine indica pada 3 HSA

\begin{tabular}{|c|c|c|c|c|c|c|}
\hline \multirow{2}{*}{$\begin{array}{c}\text { Cuka } \\
(\%)\end{array}$} & \multicolumn{6}{|c|}{ Lerak (\%) } \\
\hline & 0 & & 2,5 & & 5 & \\
\hline \multirow{2}{*}{0} & 0 & $\mathrm{a}$ & 0 & $\mathrm{a}$ & 0 & $\mathrm{a}$ \\
\hline & A & & A & & A & \\
\hline \multirow{2}{*}{5} & 0 & $\mathrm{a}$ & 0 & $\mathrm{a}$ & 0 & $\mathrm{a}$ \\
\hline & A & & A & & A & \\
\hline \multirow{2}{*}{10} & 0 & $\mathrm{a}$ & 5,50 & $\mathrm{~b}$ & 6,75 & $\mathrm{~b}$ \\
\hline & A & & B & & B & \\
\hline \multirow{2}{*}{15} & 16,75 & $b$ & 35 & $\mathrm{c}$ & 48,75 & $\mathrm{c}$ \\
\hline & $\mathrm{A}$ & & B & & $\mathrm{C}$ & \\
\hline \multirow{2}{*}{20} & 28,75 & $\mathrm{c}$ & 66,75 & d & 85 & $\mathrm{~d}$ \\
\hline & A & & B & & $\mathrm{C}$ & \\
\hline
\end{tabular}

Keterangan : Angka-angka yang diikuti huruf sama, huruf kecil untuk baris dan huruf besar untuk kolom, tidak berbeda menurut uji BNT 5\%=2,60

\section{Tingkat Kehijauan Daun}

Tingkat kehijauan daun tumbuhan dipengaruhi oleh klorofil. Klorofil memiliki fungsi utama dalam fotosintesis tumbuhan. Klorofil memanfaatkan energi matahari, memicu fiksasi $\mathrm{CO}_{2}$ untuk menghasilkan karbohidrat dan menyediakan energi (Ai dan Banyo, 2011).

Hasil analisis ragam menunjukkan bahwa penurunan kehijauan daun gulma C. rotundus, $E$. indica, dan $S$. nodiflora dipengaruh interaksi konsentrasi cuka dan konsentrasi larutan buah lerak. Aplikasi terhadap C. rotundus (Tabel 4) menunjukkan bahwa penggunaan cuka 10\% tanpa ditambahkan larutan buah lerak dan disemua konsentrasi buah lerak memiliki tingkat kehijauan daun lebih rendah dibandingkan dengan kontrol. Pada konsentrasi cuka $15 \%$, pemberian campuran buah lerak 2,5 dan 5\% mampu mempengaruhi penurunan kehijauan daun dibandingkan dengan aplikasi $15 \%$ tanpa campuran. Aplikasi terhadap E. indica (Tabel 5) menunjukkan bahwa penggunaan cuka $10 \%$ tanpa ditambahkan larutan buah lerak dan disemua konsentrasi buah lerak memiliki tingkat kehijauan daun lebih rendah dibandingkan dengan kontrol. Pada konsentrasi cuka 5\%, pemberian campuran buah lerak $5 \%$ mampu mempengaruhi penurunan kehijauan daun 
Tabel 3. Pengaruh Perlakuan Cuka + Larutan Buah Lerak Terhadap Tingkat Keracunan Gulma Synedrella nodiflora pada 3 HSA

\begin{tabular}{crrrrrr}
\hline $\begin{array}{c}\text { Cuka } \\
(\%)\end{array}$ & \multicolumn{5}{r}{ Lerak (\%) } \\
\cline { 2 - 7 } 0 & 0 & 2,5 & 5 & \\
\hline \multirow{2}{*}{5} & 0 & $\mathrm{a}$ & 0 & $\mathrm{a}$ & 0 & $\mathrm{a}$ \\
& $\mathrm{A}$ & $\mathrm{A}$ & $\mathrm{A}$ & \\
\hline \multirow{2}{*}{5} & 0 & $\mathrm{a}$ & 4 & $\mathrm{~b}$ & 4 & $\mathrm{~b}$ \\
& $\mathrm{~A}$ & & $\mathrm{~B}$ & & $\mathrm{~B}$ & \\
\hline \multirow{2}{*}{10} & 87,50 & $\mathrm{~b}$ & 88 & $\mathrm{c}$ & 90 & $\mathrm{c}$ \\
& $\mathrm{A}$ & & $\mathrm{AB}$ & $\mathrm{B}$ & \\
\hline \multirow{2}{*}{15} & 100 & $\mathrm{c}$ & 100 & $\mathrm{~d}$ & 100 & $\mathrm{~d}$ \\
& $\mathrm{~A}$ & & $\mathrm{~A}$ & & $\mathrm{~A}$ & \\
\hline \multirow{2}{*}{20} & 100 & $\mathrm{c}$ & 100 & $\mathrm{~d}$ & 100 & $\mathrm{~d}$ \\
& $\mathrm{~A}$ & & $\mathrm{~A}$ & & $\mathrm{~A}$ & \\
\hline
\end{tabular}

Keterangan : Angka-angka yang diikuti huruf sama, huruf kecil untuk kolom dan huruf besar untuk baris, tidak berbeda menurut uji BNT 5\%=2,09

Tabel 4. Pengaruh Perlakuan Cuka + Larutan Buah Lerak Terhadap Tingkat Kehijauan Daun Gulma Cyperus rotundus pada 3 HSA

\begin{tabular}{crlrlrl}
\hline \multirow{2}{*}{ Cuka (\%) } & \multicolumn{5}{c}{ Lerak (\%) } \\
\cline { 2 - 7 } & 0 & 2,5 & 5,85 & \\
\hline \multirow{2}{*}{0} & 36,08 & a & 35,85 & a & 32,78 & a \\
& $\mathrm{A}$ & & $\mathrm{A}$ & $\mathrm{A}$ & \\
\hline \multirow{2}{*}{5} & 33,53 & $\mathrm{a}$ & 31,45 & $\mathrm{a}$ & 28,43 & $\mathrm{a}$ \\
& $\mathrm{A}$ & & $\mathrm{A}$ & $\mathrm{A}$ & \\
\hline \multirow{2}{*}{10} & 26,95 & $\mathrm{~b}$ & 24,08 & $\mathrm{~b}$ & 22,75 & $\mathrm{~b}$ \\
& $\mathrm{~A}$ & & $\mathrm{~A}$ & $\mathrm{~A}$ & \\
\hline \multirow{2}{*}{15} & 19,20 & $\mathrm{c}$ & 5,28 & $\mathrm{c}$ & 5,93 & $\mathrm{c}$ \\
& $\mathrm{A}$ & & $\mathrm{B}$ & $\mathrm{B}$ & \\
\hline \multirow{2}{*}{20} & 6,18 & $\mathrm{~d}$ & 3,50 & $\mathrm{c}$ & 3,78 & $\mathrm{c}$ \\
& $\mathrm{A}$ & & $\mathrm{A}$ & $\mathrm{A}$ & \\
\hline
\end{tabular}

Keterangan : Angka-angka yang diikuti huruf sama, huruf kecil untuk kolom dan huruf besar untuk baris, tidak berbeda menurut uji BNT 5\% $=5,56$

dibandingkan dengan aplikasi 5\% tanpa campuran. Pada konsentrasi cuka 10 dan $15 \%$, pemberian campuran buah lerak 2,5 dan 5\% mampu mempengaruhi penurunan kehijauan daun dibandingkan dengan aplikasi tanpa campuran. Aplikasi terhadap S. nodiflora (Tabel 6) menunjukkan bahwa penggunaan cuka $10 \%$ tanpa ditambahkan larutan buah lerak dan disemua konsentrasi buah lerak tingkat kehijauan daun lebih rendah dibandingkan dengan kontrol. Pada konsentrasi cuka $10 \%$, pemberian campuran buah lerak 5\% mampu mempengaruhi penurunan kehijauan daun dibandingkan dengan aplikasi tanpa campuran.

\section{Bobot Kering}

Perlakuan cuka dan larutan buah lerak dapat menurunkan bobot kering beberapa gulma yaitu $C$. rotundus, $E$. indica, dan $S$. nodiflora namun tidak ada interaksi antara cuka dan larutan buah lerak. Perlakuan cuka dapat menurunkan bobot kering gulma C. rotundus pada konsentrasi 15 dan $20 \%$. Perlakuan cuka 10-20\% mampu menurunkan bobot kering gulma $E$. indica dan $S$. nodiflora, sedangkan penambahan larutan buah lerak 2,5 dan 5\% mampu mempengaruhi penurunan bobot kering guma $E$. indica (Tabel 7). 
Tabel 5. Pengaruh Perlakuan Cuka + Larutan Buah Lerak Terhadap Tingkat Kehijauan Daun Gulma Eleusine indica pada 3 HSA

\begin{tabular}{|c|c|c|c|c|c|c|}
\hline \multirow{2}{*}{ Cuka (\%) } & \multicolumn{6}{|c|}{ Lerak (\%) } \\
\hline & 0 & & 2,5 & & 5 & \\
\hline \multirow{2}{*}{0} & 39,43 & $\mathrm{a}$ & 39,38 & $\mathrm{a}$ & 35,52 & $\mathrm{a}$ \\
\hline & A & & A & & A & \\
\hline \multirow{2}{*}{5} & 36,23 & $\mathrm{a}$ & 37,30 & $\mathrm{a}$ & 31,60 & $\mathrm{a}$ \\
\hline & A & & A & & B & \\
\hline \multirow{2}{*}{10} & 24,60 & b & 19,16 & $\mathrm{~b}$ & 19,20 & b \\
\hline & A & & B & & B & \\
\hline \multirow{2}{*}{15} & 21,20 & $\mathrm{~b}$ & 3,68 & $\mathrm{c}$ & 3,28 & c \\
\hline & A & & B & & B & \\
\hline \multirow{2}{*}{20} & 3,56 & $\mathrm{c}$ & 1,90 & $\mathrm{c}$ & 2,88 & $\mathrm{c}$ \\
\hline & A & & A & & A & \\
\hline
\end{tabular}

Keterangan : Angka-angka yang diikuti huruf sama, huruf kecil untuk kolom dan huruf besar untuk baris, tidak berbeda menurut uji BNT 5\%=4,01

Tabel 6. Pengaruh Perlakuan Cuka + Larutan Buah Lerak Terhadap Tingkat Kehijauan Daun Gulma Synedrella nodiflora pada 3 HSA

\begin{tabular}{|c|c|c|c|c|c|c|}
\hline \multirow{2}{*}{ Cuka (\%) } & \multicolumn{6}{|c|}{ Lerak $(\%)$} \\
\hline & 0 & & 2,5 & & 5 & \\
\hline \multirow{2}{*}{0} & 32,51 & $\mathrm{a}$ & 32,43 & $\mathrm{a}$ & 28,67 & $\mathrm{a}$ \\
\hline & A & & $\mathrm{A}$ & & B & \\
\hline \multirow{2}{*}{5} & 30,45 & $\mathrm{~b}$ & 32,14 & $\mathrm{a}$ & 28,95 & $\mathrm{a}$ \\
\hline & $\mathrm{AB}$ & & A & & B & \\
\hline \multirow{2}{*}{10} & 6,43 & $\mathrm{c}$ & 6,28 & b & 4,23 & b \\
\hline & A & & A & & B & \\
\hline \multirow{2}{*}{15} & 4,70 & $\mathrm{~cd}$ & 4,55 & $\mathrm{bc}$ & 4,68 & $\mathrm{~b}$ \\
\hline & A & & A & & A & \\
\hline \multirow{2}{*}{20} & 4,30 & d & 4,35 & $\mathrm{c}$ & 4,97 & $\mathrm{~b}$ \\
\hline & A & & A & & A & \\
\hline
\end{tabular}

Keterangan : Angka-angka yang diikuti huruf sama, huruf kecil untuk kolom dan huruf besar untuk baris, tidak berbeda menurut uji BNT 5\%=1,84

Perbedaan respon gulma terhadap aplikasi cuka dan larutan buah lerak salah satunya disebabkan oleh perbedaan morfologi daun yang berpengaruh terhadap banyaknya droplet (butir atau tetesan cairan) herbisida yang diterima daun. Gulma daun lebar seperti $S$. nodiflora sangat respon terhadap cuka karena dapat menerima droplet herbisida lebih banyak dibandingkan dengan $C$. rotundus dan E. indica. Menurut Tjitrosoedidjo et al., (1984), faktor penting yang lain adalah intersepsi dari droplet di atas permukaan daun yang dipengaruhi oleh tegangan permukaan droplet tersebut. Adanya trikoma pada permukaan daun mencegah kontak antara droplet dan permukaan daun sehingga herbisida tidak mampu berpenetrasi dengan baik. Dalam hal ini, surfaktan diperlukan untuk menurunkan tegangan permukaan droplet sehingga droplet seolah-olah merayap membasahi permukaan daun dan kontak antara droplet dan permukaan daun rata. Menurut Fatmawati (2004), buah lerak mengandung saponin yang dapat berperan sebagai surfaktan karena bersifat hidrofilik. Menurut Matheson (1996), adanya sifat hidrofilik pada surfaktan dapat menurunkan gaya kohesi dan meningkatkan gaya adhesi serta dapat menurunkan tegangan permukaan dan 
Tabel 7. Pengaruh Cuka dan Larutan Buah Lerak Terhadap Bobot Kering Gulma Cyperus rotundus, Eleusine indica, dan Synedrella nodiflora

\begin{tabular}{|c|c|c|c|c|c|c|c|}
\hline & \multirow{3}{*}{$\begin{array}{l}\text { Perlakuan } \\
\text { Cuka 0\% (C0) }\end{array}$} & \multicolumn{6}{|c|}{ Bobot Kering (mg) } \\
\hline & & \multicolumn{2}{|c|}{$\mathrm{CR}$} & \multicolumn{2}{|c|}{ EI } & \multicolumn{2}{|c|}{$\mathrm{SN}$} \\
\hline & & 1,89 & $\mathrm{a}$ & 2,68 & $\mathrm{a}$ & 3,65 & $\mathrm{a}$ \\
\hline & Cuka 5\% (C1) & 1,84 & $a b$ & 2,44 & $a b$ & 3,44 & $\mathrm{a}$ \\
\hline & Cuka 10\% (C2) & 1,81 & $a b$ & 2,28 & $\mathrm{bc}$ & 0,78 & $\mathrm{~b}$ \\
\hline & Cuka 15\% (C3) & 1,73 & $\mathrm{bc}$ & 1,98 & $\mathrm{c}$ & 0,63 & bc \\
\hline & Cuka 20\% (C4) & 1,63 & $\mathrm{c}$ & 1,17 & $\mathrm{~d}$ & 0,38 & $\mathrm{c}$ \\
\hline \multirow{3}{*}{ (L1) } & $\begin{array}{l}\text { Lerak } 0 \%(\mathrm{~L} 0) \\
\text { Lerak } 2,5 \%\end{array}$ & 1,81 & $\mathrm{a}$ & 2,37 & $\mathrm{a}$ & 1,85 & $\mathrm{a}$ \\
\hline & & 1,76 & $\mathrm{a}$ & 2,08 & $\mathrm{~b}$ & 1,79 & $\mathrm{a}$ \\
\hline & Lerak 5\% (L2) & 1,77 & $\mathrm{a}$ & 1,89 & $\mathrm{~b}$ & 1,69 & $\mathrm{a}$ \\
\hline \multirow{2}{*}{\multicolumn{2}{|c|}{ BNT 5\% }} & \multicolumn{2}{|c|}{$\mathrm{F} 1=0,16$} & \multicolumn{2}{|c|}{$\mathrm{F} 1=0,36$} & \multirow{2}{*}{\multicolumn{2}{|c|}{$\begin{array}{l}F 1=0,25 \\
F 2=0,20\end{array}$}} \\
\hline & & \multicolumn{2}{|c|}{$\mathrm{F} 2=0,12$} & \multicolumn{2}{|c|}{$\mathrm{F} 2=0,26$} & & \\
\hline
\end{tabular}

Keterangan $=\mathrm{C} 0:$ tanpa cuka, $\mathrm{C} 1:$ cuka $5 \%, \mathrm{C} 2:$ cuka $10 \%, \mathrm{C} 3:$ cuka $15 \%, \mathrm{C} 4:$ cuka $20 \%, \mathrm{~L} 0:$ tanpa lerak, L1 : lerak $2,5 \%$, L2 : lerak $5 \%$

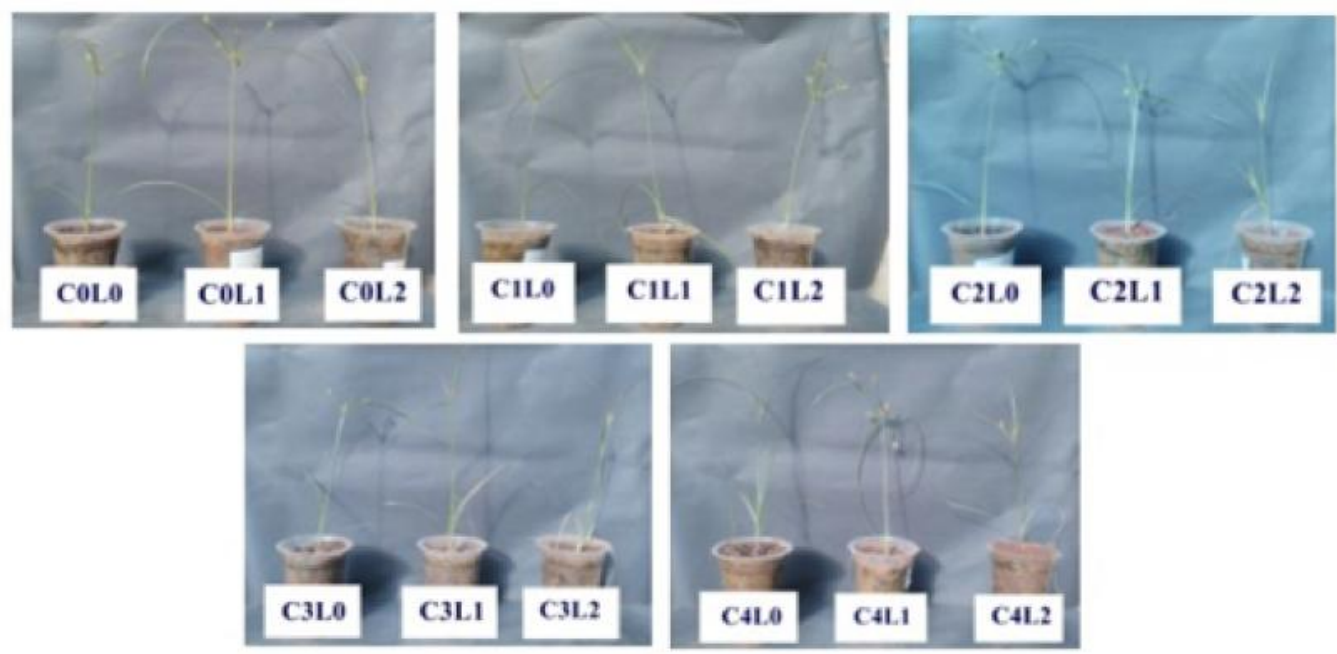

Gambar 1. Gejala keracunan gulma Cyperus rotundus pada pengamatan 3 HSA Keterangan $=\mathrm{C} 0$ : tanpa cuka, $\mathrm{C} 1$ : cuka 5\%, C2 : cuka 10\%, C3 : cuka 15\%, C4 : cuka 20\%, L0 : tanpa lerak, L1 : lerak 2,5\%, L2 : lerak 5\% 


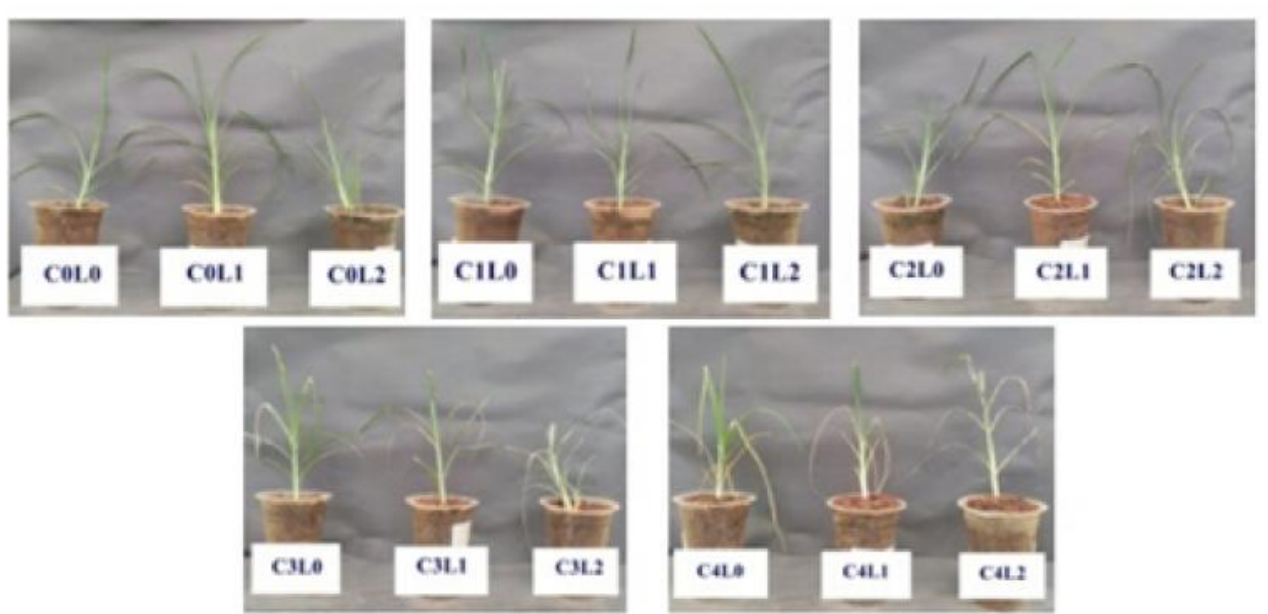

Gambar 2. Gejala keracunan gulma Eleusine indica pada pengamatan 3 HSA
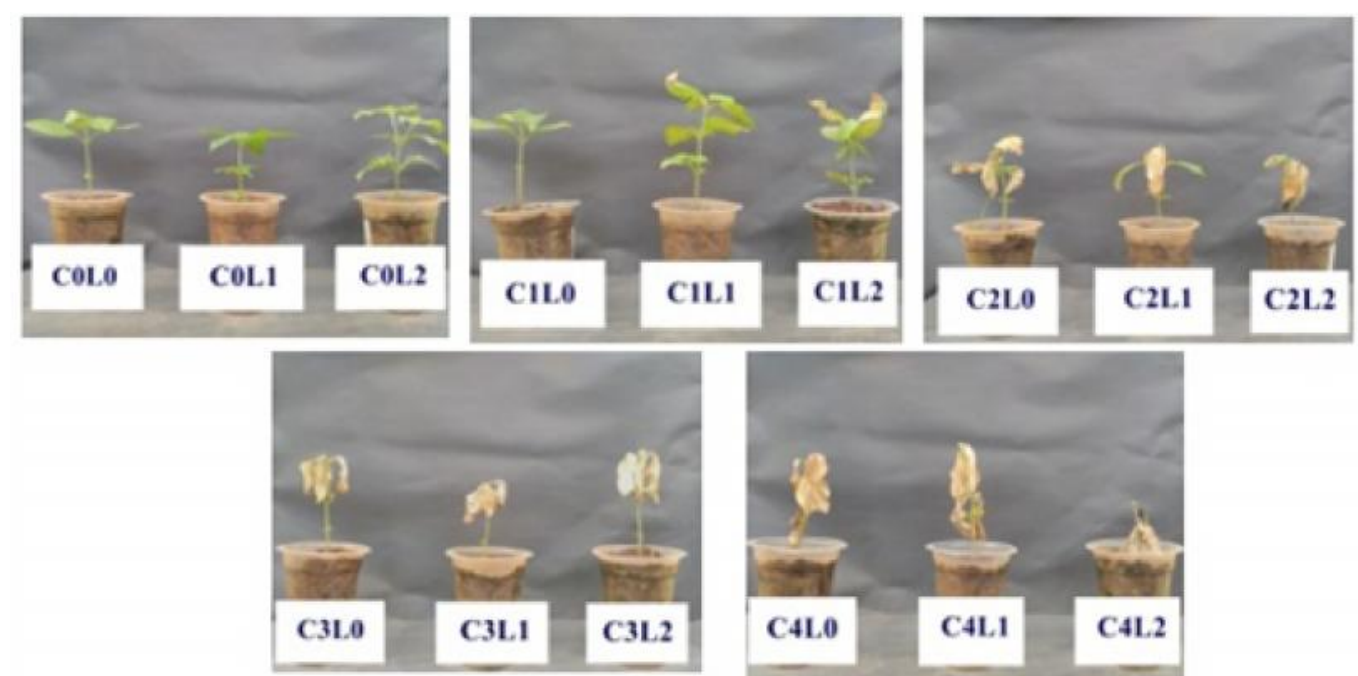

Gambar 3. Gejala keracunan gulma Synedrella nodiflora pada pengamatan 3 HSA Keterangan $=$ C0 : tanpa cuka, C1 : cuka 5\%, C2 : cuka 10\%, C3 : cuka 15\%, C4 : cuka 20\%, L0 : tanpa lerak, L1 : lerak 2,5\%, L2 : lerak 5\%

dan tegangan antarmuka cairan sehingga penambahan larutan buah lerak dapat meningkatkan efektivitas cuka.

\section{KESIMPULAN}

Kesimpulan yang diperoleh berdasarkan penelitian yang dilakukan yaitu penambahan larutan buah lerak 2,5 dan 5\% sebagai ajuvan pada cuka $15 \%$ memiliki tingkat keracunan lebih tinggi dibandingkan dengan aplikasi cuka tunggal terhadap gulma $C$. Rotundus dan E. Indica. Kombinasi cuka dan larutan buah lerak dibawah $20 \%$ yang memiliki efektivitas yang sama dengan cuka $20 \%$ adalah $15 \%+2,5 \%$ pada gulma $C$. rotundus dan $S$. nodiflora yang ditandai dengan menurunnya tingkat kehijauan daun dan bobot kering gulma.

\section{DAFTAR PUSTAKA}

Ai, N. S. Dan Y. Banyo. 2011. Konsentrasi Klorofil Daun Sebagai Indikator Kekurangan Air Pada Tanaman. Jurnal Ilmiah Sains 11 (2) : 166-173.

Chinery, D. 2002. Using Acetic Acid (Vinegar) As A Broad-Spectrum Herbicide. Cooperatif Extension Educator, Cornell Cooperative Extentsion of Rensselaer Country, 61 state street, try NY. 
Fatmawati, Ira. 2014. Efektivitas Buah Lerak (Sapindus rarak De Candole) sebagai Bahan Pembersih Logam Perak, Perunggu, dan Besi. Jurnal Konservasi Cagar Budaya Borobudur 8 (2) : 24-31.

Matheson, K. L. 1996. Formulation of Household and Industrial Detergents. In Soap and Detergents, A Theoretical and Practical Review. AOCS Press. Champaign-Illinois.

Nurtjahyani, S. N. dan I. Murtini. 2015. Karakterisasi Tanaman Cabai Yang Terserang Hama Kutu Kebul (Bemisia tabaci). University Research Colloquium.

Owen, M. D. K. 2002. Acetic acid (vinegar) for weed control revisited. Organic weed management workshop on July 1, No. 11 : 91.

Pujisiswanto, H. 2012. Kajian Daya Racun Cuka (Asam Asetat) Terhadap Pertumbuhan Gulma Pada Persiapan Lahan. Agrin Vol. 16, No.1.

Pujisiswanto, H. 2015. Mekanisme dan Efektivitas Asam Asetat Sebagai Herbisida Terhadap Gulma Pada Jagung (Zea mays L.). Disertasi S3 Universitas Gadjah Mada. Yogyakarta.

Syahroni, Yan Yanuar dan Djoko Prijono. 2013. Aktivitas Insektisida Ekstrak Buah Piper aduncum L. (Piperaceae) dan Sapindus rarak DC. (Sapindaceae) serta Campurannya Terhadap Larva Crocidolomia pavonana (F.) (Lepidoptera : Crambidae). Jurnal Entomologi Indonesia 10 (1) : 39-50.

Tjitrosoedidjo, J., I. H. Utomo, J. Wiroatmodjo. 1984. Pengelolaan Gulma di Perkebunan. Gramedia. Jakarta. 